\title{
The role of Bi on the upgrade of hypozonal gold deposits: an example from southeast Brazil
}

\author{
Mariana Brando Soares ${ }^{1}$, Atlas Vasconcelos Corrêa \\ $\mathrm{Neto}^{2}$, Felipe Emerson André Alves ${ }^{2}$ \\ ${ }^{1}$ Universidade do Estado do Rio de Janeiro, Brazil \\ (mbrandosoares@gmail.com) \\ ${ }^{2}$ Universidade Federal do Rio de Janeiro, Brazil \\ (correa.neto@geologia.ufrj.br; felipe481642@gmail.com)
}

Gold-bismuth associations have been considered pivotal to the understanding of processes regarding gold deposition and remobilization. Often, the "Bi collector model" is invoked to explain the role of molten $\mathrm{Bi}$ as an effective Au-scavenger. Many authors have delved into the vast compositions and textures of the Bi-bearing assemblages related to gold in deposits where $\mathrm{Au}$ and $\mathrm{Bi}$ show positive geochemical correlation $\left(r^{2} \geq 0.5\right)$. These phases have been studied to characterize fluid physicochemical conditions as a direct proxy for gold prospectivity. Gold deposits which show positive correlation between $\mathrm{Au}$ and $\mathrm{Bi}$ are mostly associated with a magmatic fluid source (epithermal, skarn, $\mathrm{Cu}-\mathrm{Au}$ porphyry, intrusion related). However, under the realm of orogenic gold, those of the hypozonal type formed from deep hot fluids are notably enriched in $\mathrm{Bi}$ and show Bi-bearing minerals in close textural association with gold. A significant part of the recent gold deposit discoveries worldwide relate to deposits this type. One recent (2014) discovery regarded as an Archean hypozonal gold ore refers to the São Sebastião deposit (0.903 Moz @ 3.78-4.39 g/t Au) in southeast Brazil. This deposit occurs within amphibolite-facies rocks of the Pitangui greenstone belt $(2.86 \mathrm{Ga})$ in the Quadrilátero Ferrífero (QF). Alike many hypozonal deposits described in the literature, São Sebastião shows sulfide disseminated replacement of primary host mineralogy in multi stages (pyrrhotite, arsenopyrite, pyrite, chalcopyrite) with textural features and phases indicative of high-temperature $\left(500-600^{\circ} \mathrm{C}\right)$, having a strong positive correlation between $\mathrm{Au}$ and $\mathrm{Bi}\left(\mathrm{r}^{2}=0.87\right)$. A careful investigation of its distinctive Bi-bearing mineralogy (SEM, EPMA) points to the existence of complex assemblages of Bi-chalcogenides and $\mathrm{Bi}$ sulfosalts as well as native bismuth and bismuthinite. Phases of the pavonite series indicate crystallization at $\sim 600^{\circ} \mathrm{C}$ from partial melts yielded by excess of As and $\mathrm{Bi}$. The fractionation of this system enabled the segregation of Bi-melts responsible for Au-scavenging both from fluids and early As-bearing sulfides favoring ore upgrade. The multistage character of most hypozonal deposits, its uncommon setting on high-grade terrains and the presence of lowmelting point components (LMCE) such as $\mathrm{Bi}, \mathrm{Te}, \mathrm{Sb}$ or $\mathrm{Tl}$ configure an unusual geochemistry and complex mineralogy hampering the characterization of exploration targets. This may be mitigated by the understanding of the LMCE-bearing mineralogy. Although concentrated in high-temperature pockets, the gold ore tends to show high fineness ( $\geq 900$; EPMA) due to the natural upgrading mechanisms. 